\title{
THE STRUCTURAL DEVELOPMENT OF A BACTERIAL VIRUS*
}

\author{
by \\ C. LEVINTHAL AND H. FISHER \\ Physics Department, University of Michigan, Ann Aybor, Michigan (U.S.A.)
}

\section{INTRODUCTION}

During the past decade a great deal of information has been accumulated about the interaction of bacterial viruses and their host cells. The bacteria-phage systems have been studied by many different biological, chemical and physical techniques in an attempt to investigate the elementary processes of growth ${ }^{1}$. However, as each new aspect of the problem has been investigated, it has become more apparent that the virus could not be considered as an independent self-reproducing entity growing in the host cell. Rather the host-virus complex which is formed after the cell is attacked, acts as a unit to produce the new phage. There have also been, during this period, great improvements in the techniques available for the electron microscopic examination of macro-molecular structures. In particular the spray drop technique of BAckUS AND WILLIAMS $^{2}$ has made it possible to do the same kind of quantitative work on morphologically recognizable structures that has been so successful in studies using biological assays. The present work was undertaken in an attempt to see what stages of the development of the virus-host complex can be followed quantitatively by microscopic examination, and to characterize as many of the precursors of the newly produced phage as possible.

Since the problem was to examine the macro-molecular structures inside the bacterium during the latent period, it was necessary to break open the cell and release its contents. We did not feel that any of the techniques presently available for cutting thin sections were sufficiently free from artifact, at least in our hands, to yield reliable information on the spatial orientation of the particles in the cell. Therefore, we made no attempt to maintain this orientation and investigated several techniques for breaking cells. The procedure found most useful was that reported by FRASER ${ }^{3}$ which makes use of decompression shock. This technique will break open the bacterial cells at a welldefined time while reducing the infectivity of a stock of T-2 virus by less than $20 \%$. Our procedure was to break cells at various times after infection and examine the released particulate material in the electron microscope. Thus only the numbers and kinds of particles seen are in any way significant, and the spatial orientation of these particles as seen on the microscope screen has in general no relationship to the orientation which existed in the unbroken cell.

* This study was supported in part by a grant from the Division of Research Grants and Fellowships of the National Institutes of Health, United States Public Health Service.

References $p .429$. 
The basic experiments consisted of infecting bacteria with virus and allowing intracellular growth to continue until stopped by chilling or breakage. Electron micrographs of decompressed samples were made in parallel with biological assays and plaque counts were made after each stage in the preparation for microscopy.

$A$. The biological procedures used were those described by ADAMS ${ }^{4}$ unless otherwise indicated. The bacteria were Escherichia coli strains $\mathrm{B}$ and $\mathrm{H}$ and their $\mathrm{T}$ 2-resistant mutants. The phage were $\mathrm{T}_{2} \mathrm{~L}$ and $\mathrm{T}_{2} \mathrm{H}$ and their $\mathrm{h}$ and $\mathrm{I}$ mutants. Adsorption of the virus to the bacteria was carried out either in nutrient broth or in phosphate buffer. In both cases the cells were taken from a rapidly growing broth culture at a concentration of $0.5-1.0 \cdot 10^{8}$ cells per $\mathrm{ml}$ and concentrated by centrifugation to $2 \cdot 1 \mathrm{O}^{8}$ cells per $\mathrm{ml}$. For infection in buffer $^{5}$, two centrifugations and washings were used to free the cells of broth; the cells were then aerated for 30 minutes to exhaust the remaining nutrient. Electron microscopic observations were made on intact and broken cells, either uninfected or infected, with an average multiplicity of about Io phage per bacteria. Where adsorption was carried out in buffer, the growth process was started by the addition of concentrated broth after sufficient time had elapsed for about $90 \%$ of the phage to be absorbed. We will designate this time as $T=0$.

$B$. Most experiments were done using a mixture of two types of genetically marked phage. The stocks most frequently used were $r_{13} h$ and wild ${ }^{6}$. This procedure had two advantages: 1 . plaques produced by infected bacteria could be distinguished by their appearance from those due to free phage; 2 . by following recombinants, the progeny phage could be distinguished from the input. Also by interchanging the time of infection of each of the two types one can insure that all of the infecting virus are contributing genetic markers to the final progeny ${ }^{\star}$.

$C$. The procedure used in breaking the cells was the same as that reported by FRASER ${ }^{3}$ with only minor modifications. It consisted of putting up to $15 \mathrm{ml}$ of the bacterial suspension into a pressure tank of volume $35^{\circ} \mathrm{ml}$. Nitrous oxide is then admitted to bring the pressure to $800 \mathrm{lbs} / \mathrm{sq}$. in., and the tank is rotated slowly to insure thorough mixing of the gas and liquid. After about one minute at full pressure, the opening of the tank is pointed down over a sterile receptacle and the valve is opened rapidly. The pressure in the tank takes some time to fall as the opening is necessarily small, but the bacteria pass from a region of high pressure in the tank to atmospheric pressure in a very short time, thus producing explosive decompression. The exact nature of the breakage process is not clear, but it probably involves a vacuolization which ruptures the cell membrane.

$D$. For electron microscopy samples of bacteria were taken from the cultures, chilled to $5^{\circ} \mathrm{C}$ and centrifuged in a refrigerated centrifuge for 3 minutes at $5000 \mathrm{~g}$. The rise in temperature during the centrifugation was less than $5^{\circ} \mathrm{C}$. The pellet of bacteria was resuspended in cold ammonium acetate and the suspension either with or without previous breakage was sprayed on the microscope screen. In all the work reported here, the samples were mixed with polystyrene latex particles before being sprayed. Thus the volume of fluid examined in each drop was known from the number of latex particles counted. Collodion screens were used which had been coated with a layer of albumin ${ }^{7}$ to produce an absorbent surface. This procedure allows microscopy of particulate material with considerably higher salt concentrations than is usually possible. All screens were shadowed with uranium before examination. In most cases, counts were made using the bacterial counting chamber under a phase contrast microscope before and after breakage to determine the fraction of the organisms broken on decompression.

$E$. In the later stages of the work a time study was made by decompressing in broth directly from the culture. The breakage time was known to within about one minute in these experiments. After preliminary centrifugation to eliminate the large fragments of bacterial debris, the material was centrifuged at $20,000 \mathrm{~g}$ for $\mathrm{I}$ hour to remove the broth from the particulate material.

\section{RESULTS}

The intracellular growth experiments of DoERMAnN ${ }^{8}$ were repeated, using the decompression shock method in order to check the effectiveness of breakage. For these experiments, the number of infected bacteria was kept small and the bacteria were placed directly in the bomb from the aerated culture. The results are shown in Fig. I. Since approximately $90 \%$ of the cells are broken, as measured under the light microscope, it can be seen that an infected bacterium broken before about 15 minutes pro-

* Cells were first infected with a small number of $r_{13} h$ and after 5 minutes with ten wild. The procedure was then reversed and after the wild had adsorbed the $r_{13} h$ was added. In the two cases the number of cells carrying the rh marker was the same. 
duces no active phage. If the breakage was prior to I6 minutes the plaques observed were mottled showing that they were due to infected cells containing both $\mathrm{r}$ and $\mathrm{r}^{+}$ markers which escaped breakage and not from virus freed by breakage. These results are in agreement with those of Doermann. The data of Fig. I and similar results obtained

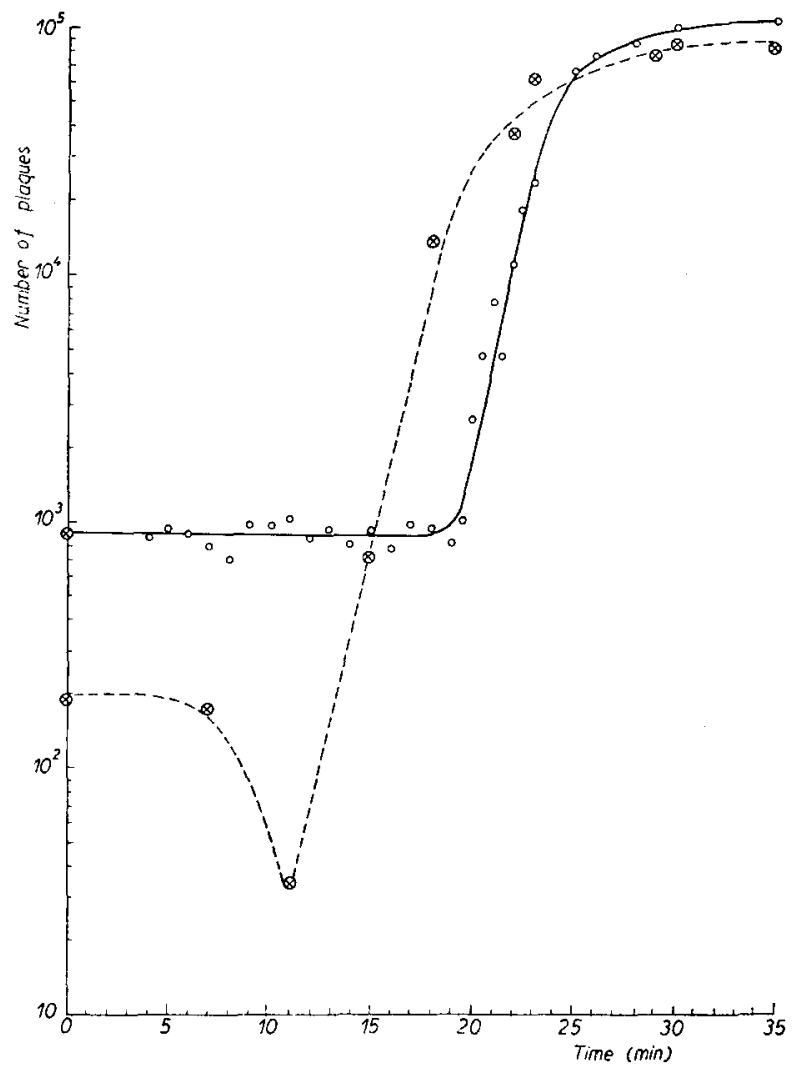

Fig. I. Intracellular growth of phage. Cells infected with an average of 4 wild and $4 r_{13}$ h phage were grown in broth at a concentration of $\mathbf{I O}^{3}$ cells $/ \mathrm{ml}$. The small circles are the plaque counts of material plated directly from the culture (one step growth curve). The circles with crosses are counts after decompression breakage. At $T=5 \mathrm{~min}$. $80 \%$ of the cells (using $10^{8}$ cells $/ \mathrm{ml}$ ) disappear under the light microscope and after $T=$ I 2 min more than $95 \%$ disappear. Before $T=20 \mathrm{~min}$ on the unbroken and $T=15 \mathrm{~min}$ on the broken sample more than $90 \%$ of the plaques are mottled. with concentrated cultures can be used to determine the effective time of growth of the cells that are put into the pressure bomb after centrifugation.

The decrease in the number of mottled plaques observed between $T=5$ and $T=\mathrm{I} 2 \mathrm{~min}$ in the broken samples was due to the increased number of cells broken by the decompression. This increased fragility was also seen in the results of cell counts made under the light microscope. In fact the cells become so fragile late in the latent period that many of them are broken by chilling and centrifugation.

The next problem was to obtain satisfactory electron micrographs of uninfected bacteria broken by this procedure. An extensive series of pictures was obtained for use as a control. These pictures were examined carefully whenever any new structures appeared in the infected cells so that observer bias could be reduced to a minimum. A few examples of such controls are shown in Fig. 2. The main characteristics noticed in the uninfected bacteria were as follows:

I. A large number of small particles of the order of 200 Angstroms in diameter was observed. These particles have been shown by SCHACHMAN, PARDEE AND STANIER ${ }^{8}$ to be a characteristic of bacterial protoplasm.

2. When the cells were taken directly from a broth culture, centrifuged, broken and the collected material sprayed within a few minutes of breakage, many have the structure shown in Fig. 2 b. However if they were allowed to stand before spraying, the exuded material would gradually disperse. These results seem to indicate that some sort of gel formation took place when the bacterial protoplasm came in contact with the surrounding liquid. 
3. If the uninfected cells had been transferred to buffer and aerated before breakage, they were much more completely smashed when subjected to decompression and the released material was dispersed, even when sprayed immediately after breakage.

4. No large organised structures except pieces of cell membrane were seen in the debris of the uninfected cells when the small particles were sufficiently dilute to prevent aggragation (Fig. 2c).

Electron micrographs of infected bacteria were taken both before and after breakage from the time $T=\mathrm{o}$ (that is, before the nutrient is added) to time $T=28$ minutes. Pictures taken before breakage served primarily as a check on the effectiveness of the centrifugation in removing broth and salts.

The micrographs of the intracellular material from infected cells broken between time $T=\mathrm{o}$ and about $T=\mathrm{r} 3$ minutes showed no evidence of any structures which were not also seen in the uninfected controls (Fig. $3 \mathrm{~b}, \mathrm{c}$ ). These negative results imply that the infecting viruses which do not reappear as biologically active units when the cell is broken, do not exist in the physical form of complete virus particles. In order to check this point more precisely the drop counting technique was used to examine a volume of $5 \cdot 10^{-8} \mathrm{ml}$. With $2 \cdot 10^{8}$ bacteria per $\mathrm{ml}$ and ro infecting virus particles per cell, there were on the average Ioo virus particles or their parts in the volume examined. No intact virus particles were seen, and, in fact, no structures of diameter larger than about $400 \mathrm{~A}$ were seen in the released debris except those which also appeared in controls and looked like small fragments of cell membrane. However, in these counting experiments we discarded the bulk of the bacterial membranes, so that only structures internal to the cell were examined. Following the discovery by HersheY ${ }^{10}$ that the phage protein separates from the nucleic acid upon infection we investigated the membranes more carefully. Near $T=$ o some structures which look like deflated phage heads were seen attached to the membranes. At later times the number of these deflated heads decreased. However quantitative work on this point is not possible without using very different techniques.

From $T=$ II minutes until the end of the normal latent period ( $T=2 \mathrm{I}$ minutes), visible changes occur very rapidly in the macro-molecular structure of the cell debris. The first sign of the new virus was seen at between II and I3 minutes with the appearance of a few "doughnut" particles. The term "doughnut" has been used to designate the structures shown in Fig. $4 \mathrm{a}, \mathrm{b}$, and c. They seem to be fibrous in nature and when dried on the microscope screen they wind up so that they often look more or less circular. Their actual appearance in the microscope is varied, but all of the patterns observed seem to be the result of the same particle drying down on the screen in different ways*. The basic fibre has a length of about $4000 \mathrm{~A}$ and a thickness of about I5O A. From the time the first "doughnuts" are found, to the first appearance of tailed phage particles approximately 3 minutes elapse. At ${ }_{5} 5$ minutes when the first phage are recognized we also see tailed particles with the same outside dimensions as phages, but with transparent flattened heads. It is in these collapsed heads that one can identify the doughnuts as producing the complex structure which was described in the heads of this phage by

* Note added in proof. We have recently been informed by Dr T. F. ANDERson that when he examines these particles with the critical point drying method, to eliminate drying artifacts, he obtains a very different view of their morphology. They appear to be the empty membranes of phage heads, similar in outline but with somewhat thicker walls than the heads of osmotically shocked ghosts. This result does not, however, alter any of the conclusions of this paper which are based entirely on particle counts.

References $p .429$. 

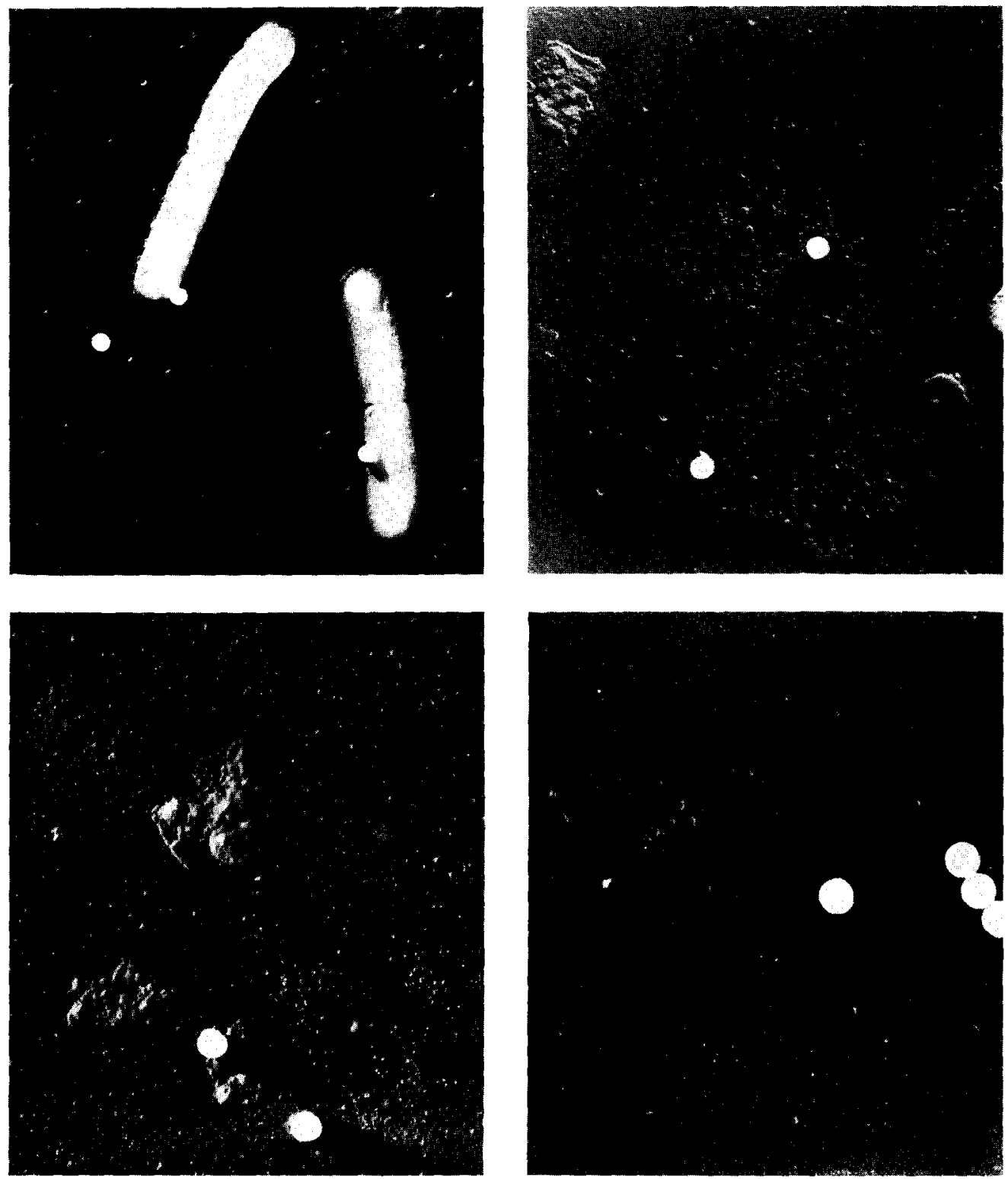

Fig. 2

a. Linbroken, uninfected bacteria. The white spheres are polystyrene latex indicator particles (P.S.L.). Vag. I $1,000 x$

b. Broken, uninfected bacterium sprayed immediately after decompression. Mag. I3,0oo $\times$

c. Broken, uninfected bacteria shows pieces of cell membrane and small particulates from protoplasm. Vay. $17,000 x$

d. A selected picture from uninfected debris after high speed centrifugation. It was selected to show the only material in controls which is of the same size as the doughnuts. There was no evidence of structure in any of these membrane pieces. Mag. $2 \mathrm{r}$, ooo $X$ 

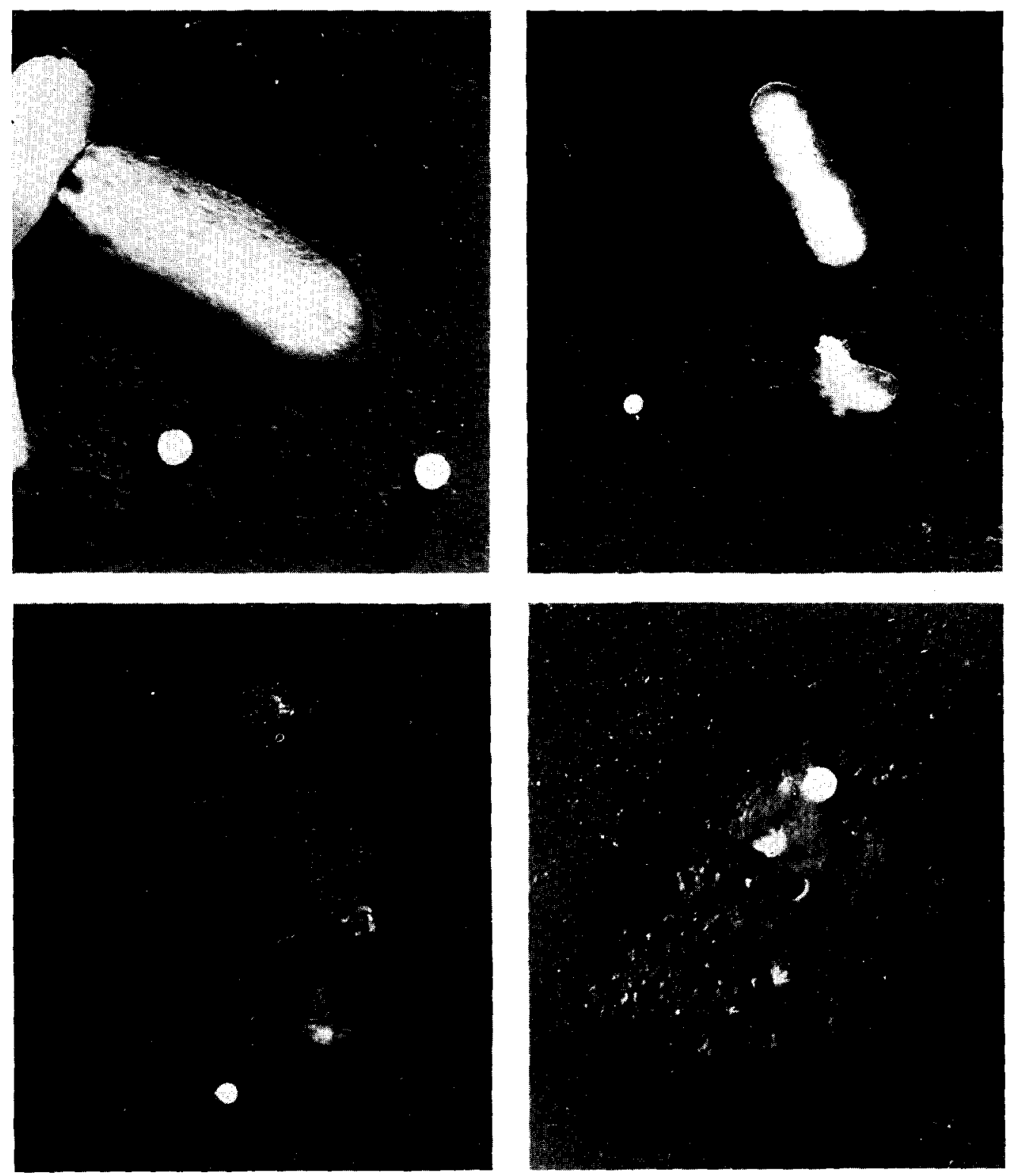

Fig. 3

a. Before breakage $T=6$ min selected to show attached phage head. Mag. 20 ,ooo $\times$

b. After decompression breakage $T=6$ min sprayed immediately. Mag. I I, ooo $\times$

c. After decompression $T=9$ min sprayed immediately. Mag. II, ooo $\times$

d. After decompression $T=12$ min sprayed immediately. This picture selected to show a few doughnuts. Mag. I 8,000 $\times$ 

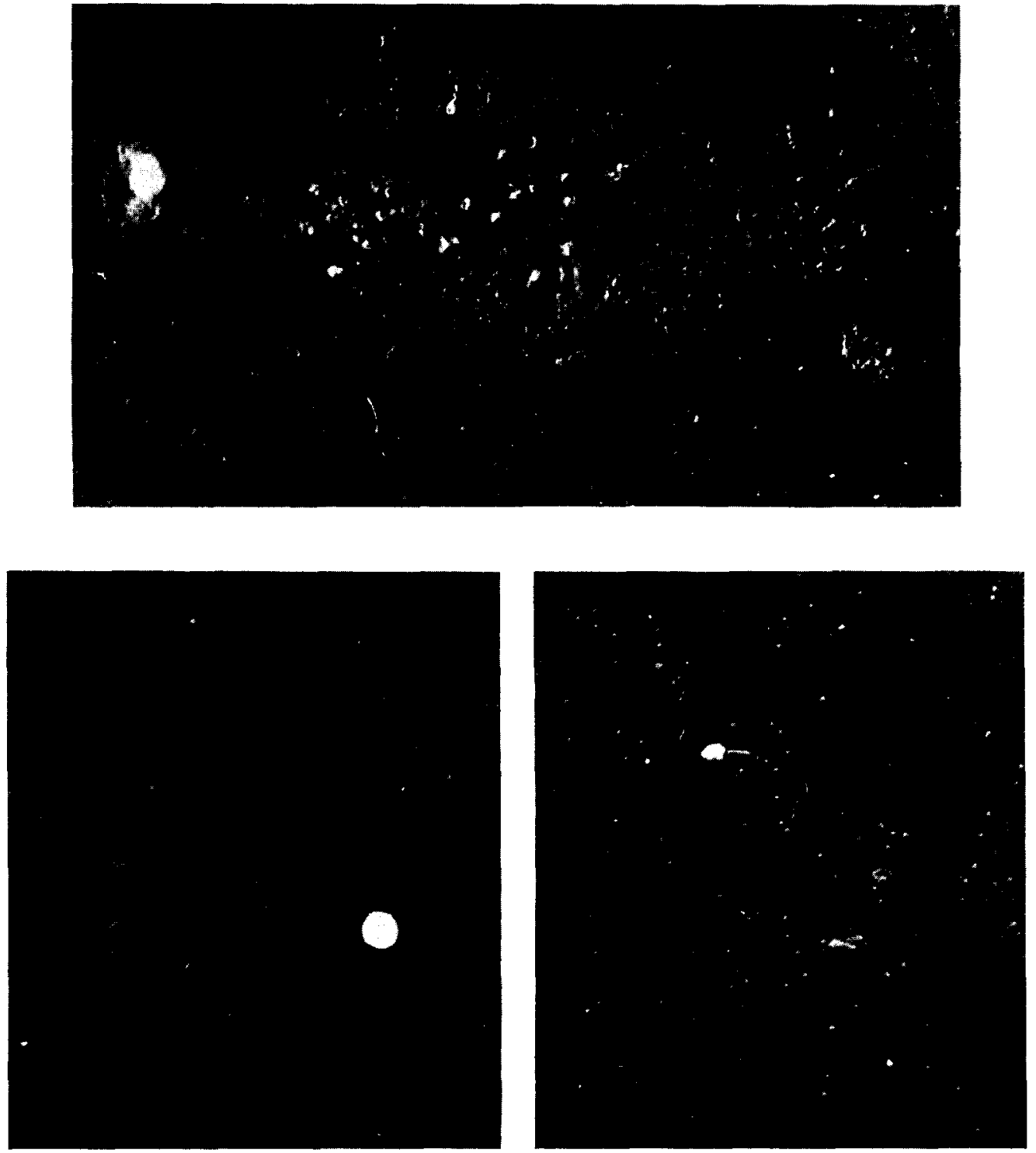

Fig. 4

a. Doughnuts in broken bacterium sprayed immediately $T=21 \mathrm{~min}$. Mag. 18 ,ooo $x$

b. Doughnuts in several shapes. Mag. 20,000 $\times$

c. The three forms noted: I. "doughnut"; 2. doughnut with tail; 3. full phage. Mag. 32,00o $\times$ 

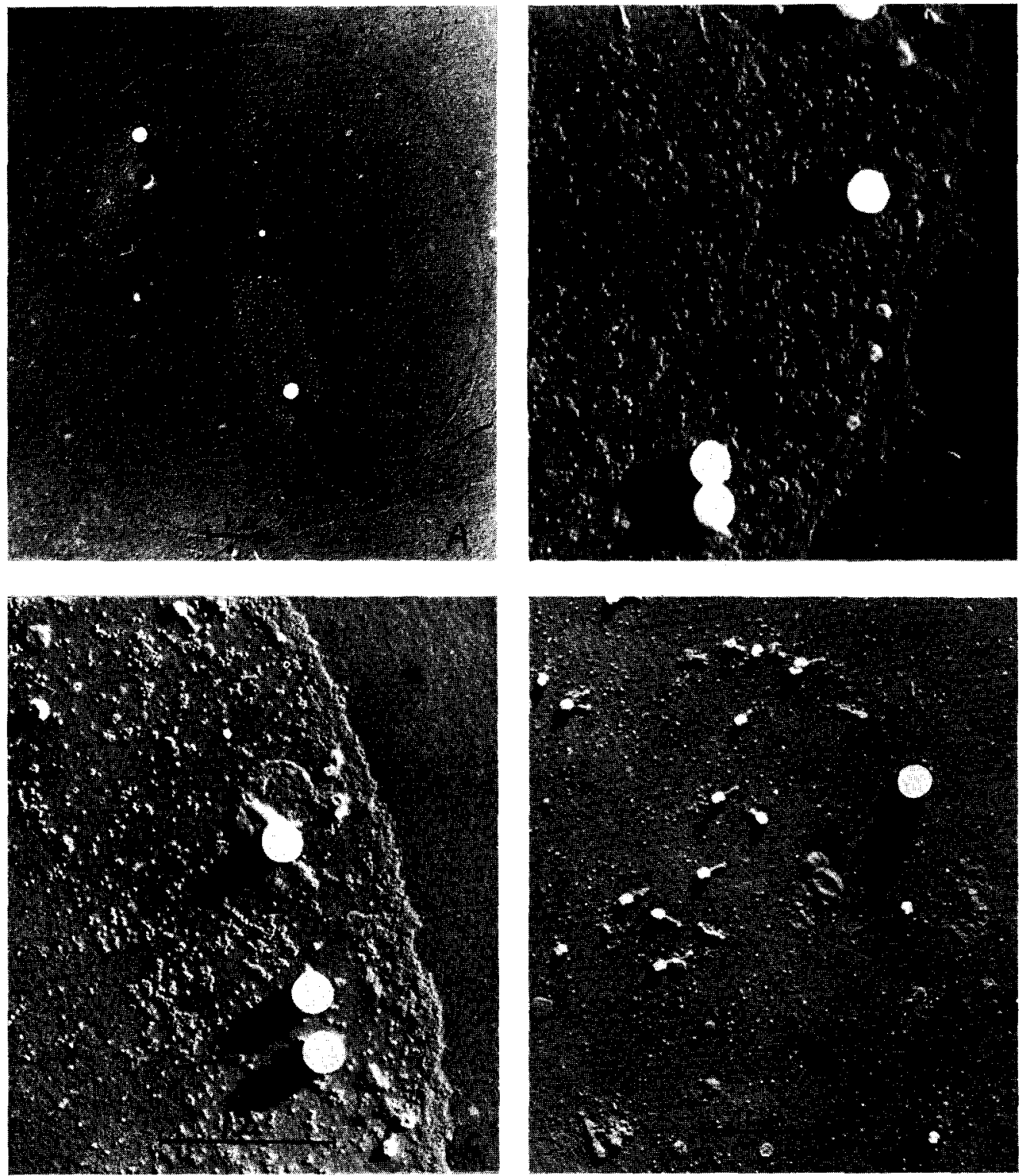

Fig. 6

a. A small $\left(\sim \mathrm{IO}^{-9} \mathrm{ml}\right.$ ) complete droplet from the $T=15 \mathrm{~min}$ sample of Fig. 5. Mag. 8,ooo $\times$ b. and c. Portions of droplets at $T=2 \mathrm{I}$ min. Mag. 24,000 $\times$

d. Portion of the center of a large droplet of the $T=25$ min sample. Mag. I 8,ooo $\times$ All prepared as indicated in the legend of Fig. 5 . 
Luria, Delbruck AND Anderson ${ }^{11}$. Finally, at the end of the latent period, when the full phage are present (Fig. 6d), we see particles with heads that do not collapse under drying and which are much more opaque to the electron beam.

Thus, in the last 7 minutes of the latent period, there are 3 kinds of particles which are recognizable and which are not found in any of the control samples: the doughnuts, then the tailed particles with flattened heads showing the doughnuts inside, and finally the phage particles themselves with opaque heads. The absolute number of phage particles per infective bacterium increases continuously from their first appearance at I5 minutes until the end of the latent period. The number of doughnuts, on the other

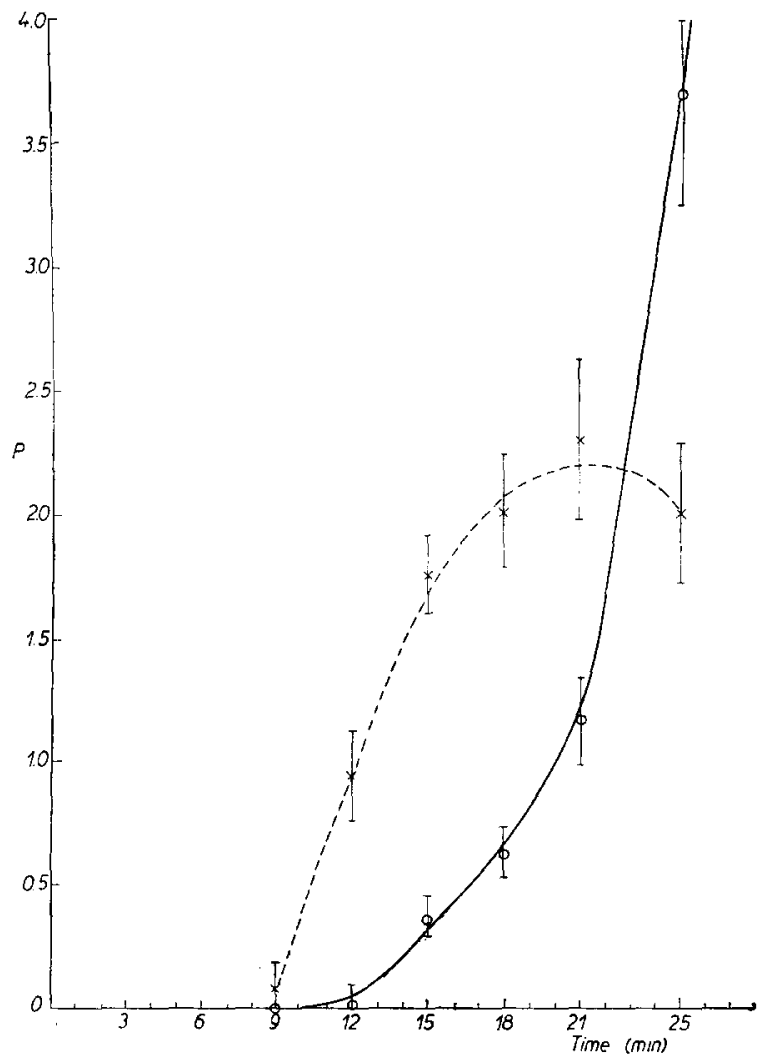

Fig. 5. Growth curve of Doughnuts and phage as determined by electron microscope count. Counts were made on samples broken directly from the growth tube which contained bacteria infected with the average of three phage. Each sample was centrifuged at low speed to remove the bacterial debris and pelleted at $20,000 \mathrm{~g}$ for one hour. $P$ represents the number of particles counted per polystyrene latex which was at a concentration of $3 \cdot 10^{\theta}$ particles $/ \mathrm{ml}$. $P=$ I means about I $_{5}$ particles per bacterium and the infection was with three virus per bacterium. The flags are the standard error due to sampling only. hand, reaches a maximum at about 2 I minutes and then levels off as though they were transformed into intact phage (see Fig. 5).

\section{CONCLUSIONS}

The absence of recognizable virus particles during the first half of the latent period shows that the eclipse phenomenon* is not due to any slight changes in the virus which makes it non-infective. Rather the disappearance of the virus infectivity is accompanied by a complete breakdown of the structural form. The initial breakdown of the input phage must be a very rapid process, since it occurs even in buffer when the absorption is made on bacteria which have been aerated in buffer for 30 minutes. It seems likely that the breakdown takes place at the stage of irreversible absorption which according to GAREN AND PUCK ${ }^{13}$ is very shortly after the first contact of the virus with the host. However, the initial breakdown in buffer is being further investigated.

From the work of LURIA AND LATARJET $^{14}$ and of BENZER ${ }^{15}$ on the radiation sensitivity of the infective centers it seems clear that growth of virus specific material is taking place during the eclipse period. The fact that we are unable to follow this

${ }^{\star}$ The term eclipse phenomenon has been used to indicate the complete disappearance of the infecting phage ${ }^{12}$.

References $p .429$. 
growth is probably due to the large number of small particles which exist in the normal uninfected bacteria and in a practical sense limit the resolution of electron microscopy of bacterial extract to distances of 200 to $300 \mathrm{~A}$. Thus, any structural changes which accompany the actual molecular growth process cannot be seen, at least with a technique which does not preserve the spatial orientation in the cells.

The "doughnut" precursors of the phage have been noted by several other observers and particularly by WYCKOFF ${ }^{16}$, HerciK ${ }^{17}$, and EPsteIN ${ }^{18}$ in lysed cultures. However the fact that the number of doughnuts increases before the first phage increase indicates that they are indeed precursors of the phage and not breakdown fragments of the newly formed virus. Also, the knowledge of time of formation of these precursors makes possible their purification and their use in determining the point at which various external agents interfere with virus production. This method has been applied by Demars, LuRIA and ourselves in a study of the stage at which proflavine stops virus production. From the very rapid increase in the number of doughnuts so late in the latent period, it seems reasonable to assume that what we are observing is the final synthesis of the already formed virus material and not the original formation of virus specific molecules.

\section{ACKNOWLEDGEMENTS}

We wish to thank Dr M. Baylor, Dr A. D. Hershey and Dr S. E. Luria for suggesting improvements on an early draft of this paper, but even more for a great deal of help and advice on general problems of phage technique.

\section{SUMMARY}

Bacteriophage precursors have been studied by breaking open infected bacterial cells and examining the intracellular material under the electron microscope. Bacterial breakage was accomplished by means of explosive decompression, a technique which will break both infected and uninfected bacteria but will not affect free virus particles. All electron microscopy was done using the spray drop method for counting the number of each type of particle found.

Studies were made at uninfected bacteria in order to establish controls. Several of the structures previously reported as virus precursors were found in these controls. Samples of infected cultures were broken at frequent intervals during the latent period and the material liberated was examined under the microscope. During the first half of the latent period no structures could be seen which were not also seen in uninfected controls. About three minutes before the first appearance of intracellular phage a particle was seen which is roughly the size of a phage head and which, when dried on the microscope screen looks like a twisted fiber. These particles, which have been called "doughnuts" increase in number, initially at the same rate as the complete phage particles. However, before the end of the normal latent period their number reaches a maximum at about 35 per bacterium and then decreases as the "doughnuts" are converted into complete phage. When the "doughnuts" and phage are at about equal number intermediate particles are seen which appear to be "doughnuts" with a phage tail attached.

\section{RÉSUMÉ}

Afin d'étudier les précurseurs du bactériophage nous avons brisé des cellules bactériennes infectées et nous en avons examiné le contenu au microscope électronique. Pour briser les cellules nous les avons soumises à une décompression explosive, technique par laquelle les cellules bactériennes infectées et non infectées sont rompues, tandis que les particules de virus libres ne sont pas attaquées. Pour compter le nombre de chaque type de particules la méthode dite "spray drop" a été employée.

A titre de comparaison, des bactéries non-infectées ont également été étudiées. Nous y avons trouvé plusieurs structures préalablement considérées comme précurseurs du bactériophage. Des prises de cultures infectées ont été traitées fréquemment pendant la période latente et la matière

References $p .429$. 
libérée a été examinée au microscope. Pendant la première moitié de la période latente nous n'avons pu observer aucune structure qui ne fût pas présente également dans les cultures non-infectées de contrôle. Environ trois minutes avant la première apparition de phage intracellulaire une particule a été observée qui avait environ la taille d'une tête de phage et qui, séché sur l'écran du microscope, avait l'aspect d'une fibre tordue. Ces particules, que l'on a appelées "doughnuts" augmentent en nombre, d'abord à la même vitesse que les particules de phage complètes; cependant, avant la fin de la période latente normale leur nombre atteint un maximum à environ 35 par bactérie, puis il décroît tandis que les "doughnuts" sont transformés en phages complets. Lorsque les "doughnuts" et phages sont environ en nombre égal, l'on aperçoit des particules intermédiaires qui ont l'air de "doughnuts" portant une queue de phage.

\section{ZUSAMMENFASSUNG}

Vorläufer der Bakteriophagen wurden untersucht, indem infizierte Bakterienzellen aufgebrochen und ihr Inhalt elektronenmikroskopisch geprüft wurde. Die Bakterienzellen wurden durch eine explosionsartige Dekompression aufgebrochen, eine Arbeitstechnik bei welcher sowohl infizierte wie nicht infizierte Bakterien nicht aber freie Virusteilchen angegriffen werden. Um die Anzahl jeder Art von Teilchen festzustellen bedienten wir uns der sogenannten "Spray drop"-Methode.

$\mathrm{Zu}$ Vergleichszwecken wurden auch nicht-infizierte Bakterien untersucht. Mehrere Strukturen, die früher als Virus-Vorläufer beschrieben worden waren, wurden in diesen Vergleichsansätzen gefunden. Proben von infizierten Bakterien wurden während der latenten Periode in kurzen Abständen aufgeschlossen und das freigemachte Material wurde unter dem Mikroskop untersucht. Während der ersten Hälfte der latenten Periode wurden keine Strukturen wahrgenommen, die nicht auch in den nicht infizierten Vergleichsansätzen vorkamen. Ungefähr drei Minuten vor dem ersten Auftreten von intrazellularem Bakteriophag wurde ein Teilchen beobachtet, dessen Grösse ungefähr derjenigen eines Bakteriophagen-Kopfes entsprach und welches auf dem Mikroskop-Schirm getrocknet wie eine gedrehte Faser aussah. Die Anzahl dieser Teilchen, welche "doughnuts" genannt worden sind, nimmt anfangs mit derselben Geschwindigkeit $\mathrm{zu}$, wie diejenige der vollständigen Phagen. Vor dem Ende der normalen latenten Periode erreicht ihre Zahl bei 35 pro Bakterie ein Maximum und nimmt dann $\mathrm{ab}$, während die "doughnuts" sich in Phagen verwandeln. Wenn die Zahl der "doughnuts" und der Phagen ungefähr gleich gross ist, sieht man Utbergangsformen, welche wie "doughnuts" mit einem Phagen-Schwanz aussehen.

\section{REFERENCES}

1 Viruses I950, Division of Biology of the California Institute of Technology, edited by M. DELBRUCK.

2 R. C. Backus and R. C. Williams, J. Applied Phys., 2 I (I950) II.

3 D. Fraser, Nature, I67 (195I) 33.

4 M. H. Adams, Methods in Medical Research, Vol. II. The Year Book Publishers, Chicago (1950).

5 R. Dulbecco, J. Bact., 59 (1950) 329.

6 A. D. Hershey and R. Rotman, Genetics, 34 (I949) 44.

7 S. E. Luria, R. C. Williams, and R. C. BaCkus, J. Bact., 6I (I95I) I 79.

8 A. H. Doermann, J. Gen. Physiol., 35 (I952) 645.

- H. K. Schachman, A. B. Pardee, and R. Y. STANier, personal communication.

10 A. D. Hershey and MARY Chase, personal communication.

11 S. E. Luria, M. Delbruck, and T. F. Anderson, J. Bact., 46 (ig43) 57.

12 S. E. LURIA, Science, III (1950) 507.

13 T. Puck, A. Garen, and J. Cline, J. Exptl. Med., 93 (I95I) 65.

14 S. E. Luria and R. Latarjet, J. Bact., 53 (1947) 149.

$15 \mathrm{~S}$. BENZER, J. Bact., 63 (I952) 59.

16 R. W. G. Wyckoff, Electron Microscopy. Interscience Publishers, New York (1949).

17 F. Hercik, Casopis Lekartu Ceskych, 89 (I950b) 89.

${ }^{18}$ H. Epstein, personal communication. 